\title{
Impact of Hydroelectric Projects on Bivalve Clams in the Sharavathi Estuary of Indian West Coast
}

\author{
M. Boominathan ${ }^{\mathrm{a}, \mathrm{b}}$, G. Ravikumar ${ }^{\mathrm{b}}$, M. D. Subash Chandran ${ }^{\mathrm{a}}$ and T. V. Ramachandra, ${ }^{\mathrm{a}, *}$ \\ ${ }^{a}$ Energy and Wetlands Research Group, Centre for Ecological Sciences, Indian Institute of Science, Bangalore - \\ 560012, India \\ ${ }^{b}$ A.V.V.M. Sri Pushpam College, Poondi - 613503, Tamil Nadu, India
}

\begin{abstract}
The impact of freshwater discharges from upstream hydroelectric projects on estuarine ecology, particularly on commercial bivalves was seldom ever studied, despite the fact that they contribute substantially to local livelihoods. Such projects have been executed in many rivers of Indian Western Ghats unmindful of their ecological consequences. Through a period of the past five decades, two hydroelectric projects were commissioned in the river Sharavathi of central west coast, in the district of Uttara Kannada, Karnataka. Obvious consequences were on mangrove vegetation and fishery, and the livelihoods of fisher-folks were also badly affected. This study in the Sharavathi estuary is with the special objective of assessing the impact on commercial clams of incessant releases of freshwater after power production. For comparison, the study was also carried out in the undammed Gangavali River estuary in the same district. The study covers the diversity and distribution of commercial bivalves in relation to salinity, the key factor that expectedly gets altered due to freshwater releases from dams. The status of bivalves was collected through primary observations, interviews with local fisher-folks, and based on earlier studies. Whereas clam fishery involving Paphia malabarica, Meretrix meretrix, M. casta, Tegillarca granosa, Polymesoda erosa and Villorita cyprinoides goes on rather unchanged in Gangavali estuary, Sharavathi witnessed collapse of clam fishery, following salinity decline, indicative collapse of estuarine ecosystems itself. All clams gathered earlier, barring a lone species Polymesoda erosa, tolerant of low salinity remained here.
\end{abstract}

Keywords: Bivalves, dam, hydroelectric project, livelihood, salinity, Sharavathi estuary.

\section{INTRODUCTION}

Increase in estuarine salinity due to upstream dam construction in the river for water diversion for various human wants such as irrigation, industry, domestic needs, etc. is a well-established fact. Such salinity increases due to human interventions can create changes in the composition of estuarine fauna (Chen 2005, Dandekar 2012, Estevez 2002, Rodriguez et al. 2001, Seddon 2000). Not much work, however exists on the salinity decrease in the estuary due to execution of hydroelectric projects in the upstream areas causing almost constant release of freshwater into the estuary following power generation. In a rather isolated study related to the second scenario Parada et al. (2012), reported the mortality of estuarine molluscan community on account of salinity decline in the estuary of Ulla River of Spain due to an upstream hydroelectric project. Salinity and substratum composition (for instance, sand-silt-clay mix) are the main factors influencing the estuarine molluscs (Harkantra 1975a, Kanaya and Kikuchi, 2008; Mohan and Velayudhan 1998, Parker 1959, Sundaram and Shafee 1989). In the case of Ulla estuary, salinity reduction directly

*Address correspondence to this author at the Energy and Wetlands Research Group, Centre for Ecological Sciences, Indian Institute of Science, Bangalore - 560012, India; Tel: 91-80-22933099/22933503; Ext: 107; Fax: 91-80-23601428/23600085/23600683; E-mail: cestvr@ces.iisc.ernet.in or in synergy with other factors, caused the bivalve mortality when its level declined below the optimum or lasted for long periods (Parada et al. 2012).

In India, estuarine molluscan resources, especially clams and oysters, contribute to the livelihoods of many people (Boominathan et al. 2008, Rao et al. 1989, Rao and Rao 1985). Overexploitation, shell and sand mining in the estuarine areas are widely considered as major causes for the depletion of molluscs. The estuary of the river Sharavathi was once known for good production of bivalves, (Alagarswami and Narasimham 1973), a scarcity of which experienced in 1980, attributed to dam related salinity decline, although some clams were still available closer to the river mouth (Rao and Rao 1985). By 1984, the clams had disappeared in the Sharavathi estuary, when salinity measured merely $1 \mathrm{ppt}$ at $2 \mathrm{~km}$ upstream, even in February about 3 months after the rainy season (Rao et al. 1989). However, the euryhaline (tolerance of wide range salinity) species Polymesoda erosa, was reported as present in the estuary (Ingole et al. 2002).

Gangavali, yet another estuary of Uttara Kannada, also had extensive clam resources (Alagarswami and Narasimham 1973). For no known reason clams were not found in the estuary in 1984. Minor harvests of $M$. casta and Paphia malabarica before 1980 was reported (Rao et al. 1989). However, in Gangavali estuary bivalve harvesting is 

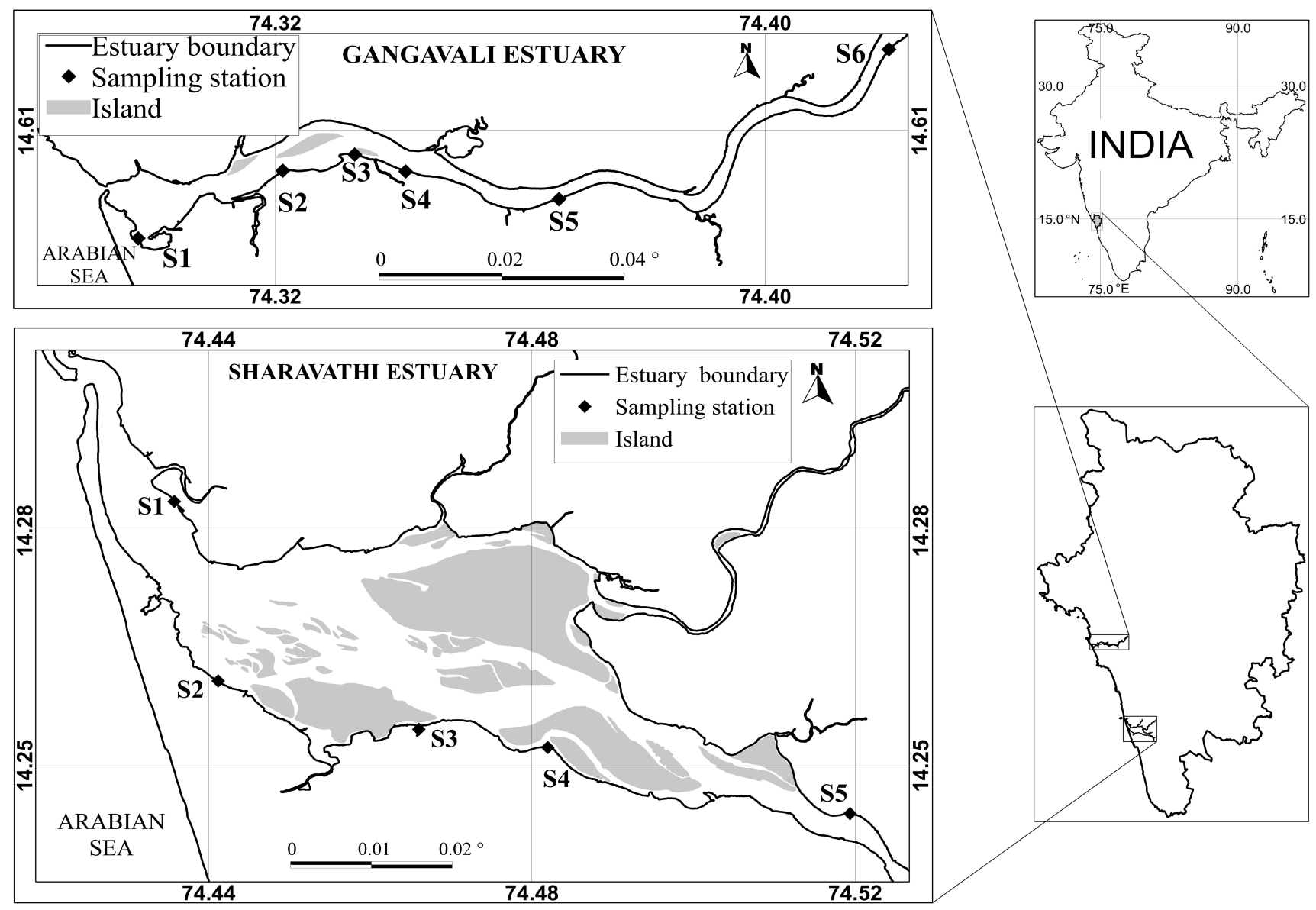

Fig. (1). Gangavali and Sharavathi estuaries in Uttara Kannada district. Abbreviations of station code as given in the Table 1.

an important livelihood activity these years. Hypothesizing that hydroelectric projects related salinity decline has adversely affected estuarine bivalves of Sharavathi in comparison with Gangavali unaffected by dams we undertook the current study.

\section{MATERIALS AND METHODS}

\section{Study Area}

The survey was conducted on the Sharavathi and the Gangavali estuaries along the Arabian Sea coast of Uttara Kannada district in South-west India, in the Karnataka State during August 2011 to July 2012 (Fig. 1). The study area map was created in QGIS version 1.8.0 (Quantum GIS Development Team, 2012). Sharavathi originates in the Western Ghats of Tirthahalli Taluk of Shimoga district and has a total length of $128 \mathrm{~km}$ to its river mouth close to Honavar town. The estuarine portion was traditionally understood to having extended from the river mouth to Gerusoppa, about $27 \mathrm{~km}$ upstream, towards the foothills of the Western Ghats. The total area of the estuarine portion was stated to be 1600 ha (Kamath 1985, Rao et al. 1989). Sharavathi has a power generation history dating back to commissioning in 1948 of a 120 MW power house in it
(Jog Management Authority 2014), now with 139.20 MW capacity. In 1964 a large dam was built at Linganmakki with a 55 MW power generation capacity. Using the waters Linganmakki dam Sharavathi Power Generating Station was commissioned with 10 units and installed capacity of 1035 MW. One more dam was commissioned at Gersoppa in 1999 with an additional power generation capacity of $240 \mathrm{MW}$ (Karnataka Power Corporation Ltd., 2011).

The river Bedti or Gangavali originates in the Dharwad district, towards the eastern fringes of the Western Ghats, bordering the Deccan, and has a total westward course of $161 \mathrm{~km}$ to its river mouth close to Ankola town in Uttara Kannada. In the Gangavali river, which has no hydel project, the high tide from the sea travels upstream to a village Gundbale, about $15 \mathrm{~km}$ interior. The estuarine of the river is spread an area of about 640 ha (Kamath 1985, Rao et al. 1989).

\section{Salinity Measurement}

Surface water salinity was measured in both the estuaries, in the field itself, during high tide using EXTECH EC 400 salinity meter in December 2011, after the total stoppage of the rainy season. In Gangavali, unaffected by dams, salinity was measured in six stations covering a total distance of 


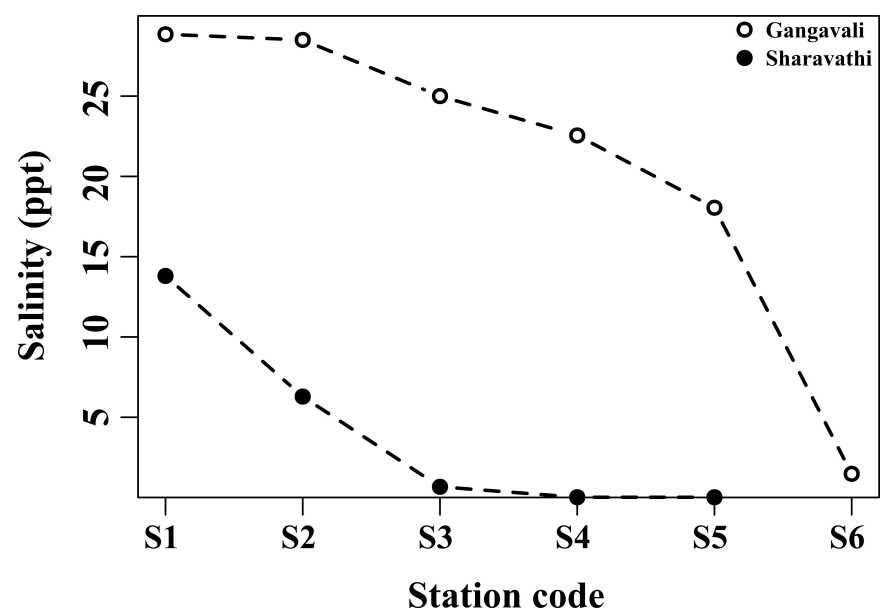

Fig. (2). Station-wise high tide salinity status in December 2011 in Gangavali and Sharavathi estuaries. Abbreviations of station code as given in the Table $\mathbf{1}$.

about $15 \mathrm{~km}$ upstream until the upstream limit of marine tides beyond which no estuarine bivalves were to be found. In Sharavathi estuary, with two hydroelectric projects upstream in the river, salinity was measured from five stations covering a total distance of $12 \mathrm{~km}$ upstream. The salinity status line graph was prepared by using statistical software R version 3.0.2 (R Development Core Team, 2013).

\section{Bivalve Data Collection}

Bivalve studies are normally conducted in the respective species specific habitats. Mudflats and sandy bottoms were known as preferred habitats for some common commercial estuarine clams of the Indian west coast such as Meretrix casta, M. meretrix, Paphia malabarica, Polymesoda erosa, Tegillarca granosa, and Villorita cyprinoides (Apte 1998, Boominathan et al. 2008). As expectedly these clams also occurred in the Aghanashini estuary of Uttara Kannada (Boominathan et al. 2008), situated between the case study areas of Gangavali and Sharavathi estuaries. All out searches were made during low tides in the mudflat and sandy bottom of Gangavali and Sharavathi estuaries for these common clams of the Indian west coast. Professional clam collectors' help was also taken in collecting the clams from their expected habitats such as mudflats and sandy bottoms. As sand mining was happening in the upstream parts of the Sharavathi estuary mined sand also was searched for clams. In addition, 20 fisher-folks of Gangavali and 25 of Sharavathi estuaries were shown specimens of different clams of the region to ascertain their locations of occurrence in the respective estuaries, currently or in the past. The clam bivalve shells collected were identified using the diagnostic characters given in the relevant literature (Apte 1998, Dey 2006, Morton 1984, Rao 1989, Rao et al. 1989). The past studies on clam bivalves from the Gangavali and the Sharavathi estuaries (Alagarswami and Narasimham 1973, Rao et al. 1989, Rao and Rao 1985) were also referred to, for understanding any changes that might have taken place in their occurrence currently. The limitation of the current study, admittedly, is the paucity of earlier published studies on Sharavathi dealing with the species-wise ranges of clam distribution. The few earlier works available focused mainly on one or few commercial species than the entire range of commercial bivalves that would have occurred in the estuary.

\section{RESULTS}

\section{Salinity}

In Gangavali estuary highest salinity recorded (in December 2011) was $28.85 \mathrm{ppt}$ (station 1) and it decreased progressively in more upstream stations. Station 6 the most upstream one at $15 \mathrm{~km}$ from the river mouth had $1.48 \mathrm{ppt}$ salinity. Sharavathi estuary, in comparison, had much lower salinities, ranging from $13.80 \mathrm{ppt}$ in station 1 to $0.02 \mathrm{ppt}$ in station 5. It is notable that at station 3 (6 km upstream) itself salinity was just 0.67 ppt (Fig. 2).

\section{Clam Distribution}

The Gangavali estuary, unaffected by hydroelectric projects, continues to have all the commercial clams reported in earlier studies. Polymesoda erosa was the only clam present in the Sharavathi estuary. The clam occurred in small quantities in stations 1 and 2 closer to the river mouth. The other clams which were recorded in earlier studies such as Meretrix meretrix and Meretrix casta could not be traced. Details of the clam distribution in relation to stations and salinity in the Gangavali and Sharavathi estuaries are given in Table $\mathbf{1 .}$

\section{DISCUSSION}

Along the coast of Uttara Kannada district harvest and sale of estuarine bivalves have been an important livelihood activity. The commercial bivalves played a key role in nutritional security of thousands of families and also generated a reasonable income, especially for women bivalve harvesters, who have otherwise very little role in the regular marine or estuarine fisheries using boats and nets (Boominathan et al. 2008). Unfortunately, this scenario has been changing rapidly in the recent years due to various threats like unrestricted shell and sand mining, shrimp aquaculture and over-exploitation of bivalves to meet growing demands from far away urban markets. Practically very little was known earlier about what the impact would be on bivalves from execution of large hydroelectric projects in the upstream areas of west flowing rivers from the Western Ghats. Major dams for power generation have been established in Sharavathi and Kali rivers of Uttara Kannada 
Table 1. Station-wise distribution of clam bivalves in Gangavali and Sharavathi estuaries.

\begin{tabular}{|c|c|c|c|c|c|c|c|c|c|}
\hline \multirow{2}{*}{ Station Name } & \multirow{2}{*}{ Code } & \multirow{2}{*}{ Distance from River Mouth (km) } & \multirow{2}{*}{ Salinity (ppt) } & \multicolumn{6}{|c|}{ Species } \\
\hline & & & & Tg & Pm & $\mathbf{P e}$ & Mm & Mc & Vc \\
\hline \multicolumn{10}{|c|}{ Gangavali estuary } \\
\hline Gangavali & S1 & 1 & 28.85 & + & + & + & + & + & \\
\hline Joog & S3 & 4.5 & 25.00 & & & & & + & \\
\hline Sagadgeri & S4 & 6 & 22.55 & & & & & + & + \\
\hline Ulware & S5 & 8 & 18.05 & & & & & & + \\
\hline Honavar & S1 & 2.5 & 13.80 & & & + & & & \\
\hline Kasarkod & S2 & 4.5 & 6.29 & & & + & & & \\
\hline Hosapatna & S3 & 6 & 0.67 & & & & & & \\
\hline Kelagin-Idgunji & S4 & 8 & 0.02 & & & & & & \\
\hline Jalawalli & S5 & 12 & 0.02 & & & & & & \\
\hline
\end{tabular}

Note: Tg - Tegillarca granosa Linnaeus, Pm - Paphia malabarica Chemnitz, Pe - Polymesoda erosa Solander, Mm - Meretrix meretrix Linnaeus, Mc - Meretrix casta Chemnitz, Vc - Villorita cyprinoides Gray.

with practically very little knowledge about the likely repercussions of such gross developmental interventions on estuarine ecosystems.

The power projects in Sharavathi River have a total installed capacity of $1469.20 \mathrm{MW}$. The hydroelectric power generation history in Sharavathi began in 1948 with the 120 MW Mahatma Gandhi Power House, now with 139.20 MW capacity. The commissioning of 1964 Linganmakki dam with a 55 MW power house would not have made any perceptible impact on estuarine ecosystem as (Alagarswami and Narasimham 1973), mentioned about the existence of "extensive clam beds" dominated by Meretrix meretrix, a high salinity tolerant species, providing regular employment for about 100 clam collectors. As clams collected in those days from several estuaries of the region were mainly used for local consumption (Boominathan 2008), the exploitation would have been within sustainable limits. The scenario change happened with the use of Linganmakki dam waters for power production in the Sharavathi Generating Station, with installed capacity of $1035 \mathrm{MW}$. The maximum use of water for power production from Linganmakki dam, with a storage capacity of 4417.51 Mcum, was a major developmental intervention in a relatively small river like Sharavathi.

By 1980's the "extensive clam beds" would have declined substantially as Rao and Rao (1985), observed
M. meretrix and $M$. casta (both high salinity tolerant) as "sparsely distributed" over an area of 11 ha near the river mouth. Further upstream, $5 \mathrm{~km}$ interior near Mavinkurve islet, the "standing stock was negligible". Four years later, during February 1984, when Rao et al. (1989) surveyed 50 sample plots covering a distance of about $17 \mathrm{~km}$ from the river mouth, the clams occurred no more, and the local collectors admitted that clam fishery in Sharavathi had virtually ended about a decade earlier itself. The addition of yet another hydroelectric dam, further downstream at Gerusoppa in 1999, with a storage capacity of 166 Mcum, and installed capacity of $240 \mathrm{MW}$ of power, spelt nemesis for the clam community of Sharavathi estuary. The cumulative impact of year long water releases from upstream dams with a total installed power generation of 1469.20 MW, obviously caused a sharp fall in salinity conditions in the estuary which was between 0.67 to $13.80 \mathrm{ppt}$ at the time our study.

During our survey only Polymesoda erosa, whose known range of salinity tolerance is from 7 to $22 \mathrm{ppt}$ (Modassir, 2000), occurred in the estuary. It was also sparse and its harvest in Sharavathi was limited to meeting domestic needs of a few families. (Clemente and Ingole 2011, Gimin et al. 2004, Ingole et al. 1994, 2002, and Modassir 2000), associated the species with muddy substratum which was true for Honavar and Kasarkod stations of Sharavathi. 
Its upstream distribution range was from 2.5 to $4.5 \mathrm{~km}$ from the river mouth (Table 1). In Gangavali estuary also P. erosa (not reported earlier) was associated with muddy locations, especially in mangrove areas.

Unaffected by any dams, Gangavali continues to have $M$. meretrix and $P$. malabarica, as reported earlier (Alagarswami and Narasimham 1973, Rao et al., 1989). In addition M. casta, P. erosa, Tegillarca granosa, and Villorita cyprinoides also occurred as Gangavali estuary continues to provide natural habitats, specifically in relation to salinity gradients, for various clams. In this regard it resembles the neighbouring Aghanashini estuary, without any dams, where 8 species of commercial bivalves were found (Boominathan et al. 2008).

Villorita cyprinoides, although not recorded in earlier studies from Sharavathi, nor from the current study, was also present in the estuary until some years ago, according to local fisher-folks, who showed the shells of the species. As $V$. cyprinoides is common to the estuaries of Karnataka (Rao et al. 1989), and because of its presence in other estuaries of Uttara Kannada like Aghanashini and Kali (Boominathan et al. 2008, 2012) and Gangavali, according to the current study (Table 1), the species, in all probability, was present in Sharavathi until it was eliminated due to the dam impact. V. cyprinoides is a species that could persist in freshwater conditions for some period (Nair et al. 1984, Rao et al. 1989). However, low salinity/freshwater conditions were reported to have adverse consequences on its growth and survival (Arun 2009, Laxmilatha et al. 2005, Pillai 1991). Nair 1975, found growth retardation of $V$. cyprinoides var cochinensis in low salinity conditions. It attained larger dimensions in its optimal salinity range from $4.73 \mathrm{ppt}$ to $27.11 \mathrm{ppt}$, whereas, small sized individuals tolerated more extreme range from $0.87 \mathrm{ppt}$ to $29.85 \mathrm{ppt}$ salinity. In Kelagin-Idgunji station, about $8 \mathrm{~km}$ upstream in Sharavathi estuary, according to local fishermen, $V$. cyprinoides used to be present some years ago. Obviously dam related low salinity (0.02 ppt recorded in December 2011) would have caused its elimination. In comparison the species occurred in Ulware station, $8 \mathrm{~km}$ upstream in Gangavali, where December 2011 salinity was 18.05 ppt.

Meretrix meretrix is a high salinity species (Rao et al. 1989). In the laboratory conditions it could not withstand salinity lower to $13 \mathrm{ppt}$ (Sundaram and Shafee 1989). However, in the natural conditions, M. meretrix survived in 10.5 ppt in Kalbadevi estuary (Ranade and Kulkarni 1973), and 7.45 ppt in Kali estuary (Nair et al. 1984). The Gangavali estuary study, confirmed its presence in high salinity stations Gangavali (28.85 ppt) and Agragone (28.5 ppt). In the Sharavathi estuary, it was present almost until 56 years ago according to clam collectors. The commissioning of Gerusoppa hydel project in 1999, would have caused its extinction in a span of a few years, although we do not rule out its recurrence during drought years in the future.

M. casta is a high salinity tolerant species upto $56.00 \mathrm{ppt}$ (Durve 1963). Its growth gets arrested in low salinity conditions (Harkantra, 1975b). Abraham (1953) and Sreenivasan (1983) reported growth retardation of M. casta at $15.65 \mathrm{ppt}$ and $20 \mathrm{ppt}$ respectively. (Paradoxically
Jayawickrema and Wijeyaratne 2009), observed that $M$. casta lived well between 3 and 40 ppt salinity. In Gangavali estuary, $M$. casta occupies a salinity zone from 28.85 to $22.55 \mathrm{ppt}$ in December 2011. According to local fisher-folks $M$. casta had also persisted in the Sharavathi estuary in small numbers until a few years ago. Here again, drastic decline of salinity related to freshwater release would have caused the species elimination.

Although Tegillarca granosa prefers salinity range of 13.69 to $34.40 \mathrm{ppt}$ (Narasimham, 1988) it functioned better in salinities above $23 \mathrm{ppt}$, and more efficiently between 26 and 31 ppt (Pathansali 1963, Broom 1985). T. granosa occurred near a mangrove-mud flat area, its preferred habitat (Pathansali 1966), in the Gangavali estuary, in $28.85 \mathrm{ppt}$ salinity. Other estuaries of the district Aghanashini and Kali, have the species to this day. In all probability it would have vanished from Sharavathi due to inundation with freshwater. Paphia malabarica, also a high salinity species, present in Gangavali and Aghanashini was not found in Sharavathi. Thus sequential interpretation of historical data on Sharavathi, based on available literature and survey undertaken during the current study, including interviews with erstwhile clam collectors, as well as comparison of clam diversity situation in the Gangavali estuary of Uttara Kannada, and the earlier study in Aghanashini (Boominathan et al. 2008) suffice to establish the fact that the cumulative impact of a series of hydroelectric projects have far reaching consequences on the estuarine clams mainly because of dilution of salinity conditions.

Estuary is a place where unique environmental conditions are created by the mingling of freshwater from the river and salt water from the ocean. Mangroves are unique formations of these brackish water habitats. Several marine fishes use estuaries for spawning or as nurseries for their juveniles. Even adults of many marine fishes move into the estuary during times when salinity conditions are favourable for them. The current study, focusing on commercial clams shows how major incursions by humans, like execution of hydroelectric projects, can be adversely affecting the species diversity of clams with devastating effects on the livelihoods of scores of people who traditionally depended on the estuarine fishery for livelihood and family nutritional security. More concerted works are required for unraveling ecosystem changes in estuaries as the aftermath of dam constructions, rampantly happening in the Western Ghats.

\section{CONFLICT OF INTEREST}

The authors confirm that this article content has no conflict of interest.

\section{ACKNOWLEDGEMENTS}

This research was supported by the Ministry of Environment and Forests (MoEF), Government of India (GOI), NRDMS division, the Ministry of Science and Technology (DST), GOI and Indian Institute of Science. We thank Shrikant G Naik and Mahima Bhat for the assistance during the field work and C. Balachandran for constructive 
comments. We also thank Deepak Apte (BNHS, Mumbai), B.S. Ingole (NIO, Goa) and P. Laxmilatha (CMFRI, Kochi, Kerala) for confirmation of the identification of bivalve shells.

\section{REFERENCES}

Abraham, KC (1953) Observations on the biology of Meretrix casta (Chemnits). Journal of Zoological Society of India, 5(1), 163-90.

Alagarswami, K \& Narasimham, KA (1973) Clam, cockle and oyster resources of the Indian coasts. In: Proceedings of the symposium on living resources of the seas around India, 1968, Central Marine Fisheries Research Institute, Cochin, India 648-58. Available from: http://eprints.cmfri.org.in/2760/

Apte, D (1998) The Book of Indian Shells. Bombay Natural History Society and Oxford University Press, Mumbai, India.

Arun, AU (2009) An assessment on the influence of salinity in the growth of black clam (Villorita cyprinoides) in cage in Cochin estuary with a special emphasis on the impact of Thennermukkom salinity barrier. Aquaculture, Aquarium, Conservation and Legislation, 2(3), 31930 .

Boominathan, M, Chandran, MDS \& Ramachandra, TV (2008) Economic valuation of bivalves in the Aghanashini estuary, west coast, Karnataka. ENVIS Technical Report 30, Sahyadri conservation series-9, Centre for Ecological Sciences, Indian Institute of Science, Bangalore, India.

Boominathan, M, Ravikumar, G, Chandran, MDS \& Ramachandra, TV (2012) In: Ramanathan, AL, Sreekesh, S \& Sundararajan, M (Eds.) The impact of dams on the edible bivalves - a comparative study of Kali and Aghanashini estuaries of Uttara Kannada District, Karnataka, India. National Conference on Mangrove Wetlands and Near Shore Marine Ecosystems From Sustainability Issues to Management \& Restoration, 05-06 March 2012, School of Environmental Sciences, Jawaharlal Nehru University, New Delhi, India 45-6.

Broom, MJ (1985) The biology and culture of marine bivalve molluscs of the genus Anadara, International Center for Living Aquatic Resources Management, Manila, Philippines.

Chen, J (2005) Dams effect on coasts. In: Schwartz, M (Ed.) Encyclopedia of Coastal Science, Springer, Netherlands.

Clemente, S \& Ingole, B (2011) Recruitment of mud clam Polymesoda erosa (Solander, 1876) in a mangrove habitat of Chorao island, Goa. Brazilian Journal of Oceanography, 59(2), 153-62.

Dandekar, P (2012) Damaged rivers, collapsing fisheries: Impacts of dams on riverine fisheries in India, Available from: URL $\mathrm{http}: / / \mathrm{www}$.indiaenvironmentportal.org.in/reports-documents/damaged-rivers-collapsing-fisheries-impacts-dams-riverine-fisheriesindia (Accessed on 30 July 2013).

Dey, A (2006) Handbook on mangrove associate molluscs of Sundarbans, Zoological Survey of India, Kolkata, India.

Durve, VS (1963) A study on the rate of the filtration of the clam Meretrix casta (Chemnitz). Journal of the Marine Biological Association of India, 5(2), 221-31.

Estevez, ED (2002) Review and assessment of biotic variables and analytical methods used in estuarine inflow studies. Estuaries, 25(6), 1291-303.

Gimin, R, Mohan, R, Thinh, LV \& Griffiths, AD (2004) The relationship of shell dimensions and shell volume to live weight and soft tissue weight in the mangrove clam, Polymesoda erosa (Solander, 1786) from northern Australia. NAGA, World Fish Center Quarterly, 27(3 $\& 4), 32-5$.

Harkantra, SN (1975a) Benthos of the Kali estuary, Karwar. Mahasagar, $8(1-2), 53-8$

Harkantra, SN (1975b) Some observations on the clam beds of Kali estuary, Karwar. Mahasagar, 8(1-2), 101-08.

Ingole, BS, Krishna Kumari, L, Ansari, ZA \& Parulekar, AH (1994) New record of mangrove clam Geloina erosa (Solander, 1786) from the west coast of India. Journal Bombay Natural History Society, 91, 338-39.

Ingole, BS, Naik, S, Furtado, R, Ansari, ZA \& Chatterji, A (2002) Population characteristics of the mangrove clam Polymesoda (Geloina) erosa (solander, 1786) in the Chorao mangrove, Goa, Presented at the National Conference on Coastal Agriculture, 6-7 April 2002, Indian Council of Agricultural Research, Old Goa, India 211-12.
Jayawickrema, E \& Wijeyaratne, M (2009) Distribution and population dynamics of the edible bivalve species Meretrix casta (Chemnitz) in the Dutch canal of Sri Lanka. Sri Lanka Journal of Aquatic Sciences, 14, 29-44.

Jog Management Authority (2014) Jogfalls. Available from: URL http://www.jogfalls.in/JogFallsEN.html (Accessed on 06 July 2014).

Kamath, S.U. (Ed.) (1985) Gazetteer of India, Karnataka State Gazetteer, Uttara Kannada District, Government of Karnataka, Bangalore, India.

Kanaya, G \& Kikuchi, E (2008) Spatial changes in a macrozoobenthic community along environmental gradients in a shallow brackish lagoon facing Sendai Bay, Japan. Estuarine, Coastal and Shelf Science, 78(4), 674-84.

Karnataka Power Corporation Ltd. (2011) Dam details, Karnataka Power Corporation Ltd. Available from: URL http://www.karnatakapower.com/ (Accessed on 22 September 2011).

Laxmilatha, P, Velayudhan, TS, Kripa, V, Sharma, J \& Alloycious, PS (2005) Biology of the black clam, Villorita cyprinoides (Gray) in the backwaters of Vembanad Lake. Indian Journal of Fisheries, 52(3), 361-66.

Modassir, Y. (2000). Effect of salinity on the toxicity of mercury in mangrove clam, Polymesoda erosa (Lightfoot 1786). Asian Fisheries Science, 13(4), 335-41.

Mohan, MKR \& Velayudhan, TS (1998) Studies on the salinity tolerance of the venerid clam, Paphia malabarica (Chemnitz). Journal of the Marine Biological Association of India, 40(1 \& 2), 185-88.

Morton, B (1984) A review of Polymesoda (Geloina) Gray 1842 (Bivalvia: Corbiculacea) from Indo-Pacific mangroves. Asian Marine Biology, 1, 77-86.

Nair, GS (1975) Studies on the rate of growth of Villorita var cochinensis (Henley) from the Cochin Backwaters. Bulletin Department of Marine Science, Cochin University, 7(4), 919-30.

Nair, KN, Ramadoss, K, Rajan, CT \& Sundaram, N (1984) Molluscan resources of Kali river estuarine system in Karnataka. Marine Fisheries Information Service, Technical and Extension Series 58, Central Marine Fisheries Research Institute, Cochin, India 1-8.

Narasimham, KA (1988) Biology of the blood clam Anadara granosa (Linnaeus) in Kakinada Bay. Journal of the Marine Biological Association of India, 30(1\&2), 137-50.

Parada, JM, Molares, J \& Otero, X (2012) Multispecies mortality patterns of commercial bivalves in relation to estuarine salinity fluctuation. Estuaries and Coasts, 35(1), 132-42.

Parker, R. H. (1959). Macro-invertebrate assemblages of central Texas coastal bays and Laguna Madre. American Association of Petroleum Geologists Bulletin, 43(9), 2100-66.

Pathansali, D (1963) On the effect of salinity changes on the activity of the cockle, Anadara granosa (L). Malaysian Agricultural Journal, 44, $18-25$.

Pathansali, D (1966) Notes on the biology of the cockle Anadara granosa L. In: Proceedings of the Indo-Pacific Fisheries Council, 11, 84-98.

Pillai, VK (1991) Studies on the hydrobiology and pollution of the Vembanad Lake and adjacent waters (Ph.D.thesis). Cochin University of Science and Technology.

Quantum GIS Development Team (2012) Quantum GIS Geographic Information System. Open Source Geospatial Foundation Project. Available from: URL http://qgis.osgeo.org/

Ranade, MR \& Kulkarni, CV (1973) Observations on the behaviour of clams in waters of low salinity. Journal of Bombay Natural History Society, 69(3), 616-34.

Rao, GS, Kuriakose, PS, Ramachandran, N, Meiyappan, MM, Achari, GPK, Nagaraja, D \& Shivanna, HS (1989) Atlas of clam resources of Karnataka, Central Marine Fisheries Research Institute, Cochin, India, Special Publication 46, Available from: URL http://eprints.cmfri.org.in/3402/

Rao, GS \& Rao, KS (1985) Survey of clam and oyster resources of some Karnataka estuaries. Indian Journal of Fisheries, 32(1), 74-89.

Rao, NVS (1989) Handbook, freshwater molluscs of India, Zoological Survey of India, Calcutta, India.

R Development Core Team (2013) R: A language and environment for statistical computing. Vienna, Austria: R Foundation for Statistical Computing. Available from: URL http://www.R-project.org/

Rodriguez, CA, Flessa, KW \& Dettman, DL (2001) Effects of upstream diversion of Colorado River water on the estuarine bivalve mollusc Mulinia coloradoensis. Conservation Biology, 15(1), 249-58. 
Seddon, MB (2000) Molluscan biodiversity and the impact of large dams (Prepared for Thematic Review II.1), World Commission on Dams, Cape Town, South Africa, Available from: URL http://www.dams.org/ Accessed on 27 June 2008)

Sreenivasan, PV (1983) Growth of the clam Meretrix casta (Chemnitz) transplanted in the Vellar estuary. In: Proceedings of the
Symposium on Coastal Aquaculture, part 2, 12-18 January 1980. Marine Biological Association of India, Cochin, India 564-68. Available from: URL http://eprints.cmfri.org.in/2298/

Sundaram, KS \& Shafee, MS (1989) Salinity tolerance of some bivalves of Ennore estuary. Journal of the Marine Biological Association of India, 31(1 \& 2), 299-302.

Received: July 07, 2014

Revised: August 30, 2014

Accepted: August 30, 2014

(C) Boominathan et al.; Licensee Bentham Open.

This is an open access article licensed under the terms of the Creative Commons Attribution Non-Commercial License (http://creativecommons.org/ licenses/by-nc/3.0/), which permits unrestricted, non-commercial use, distribution and reproduction in any medium, provided the work is properly cited. 